\title{
A ARGUMENTAÇÃO JURÍdICA COMO MEIO PARA APLICAÇÃO DE METODOLOGIAS ATIVAS NO ENSINO DE DIREITO A DISTÂNCIA
}

Congresso Brasileiro Online de Direito, 1ạ edição, de 11/10/2021 a 13/10/2021

ISBN dos Anais: 978-65-89908-73-9

HARA; Johnny Marcelo ${ }^{1}$, JeSUS; Renata Menezes de ${ }^{2}$, NUNES; Flávio Fllgueiras ${ }^{3}$, JÚNIOR; Nelson Rezende ${ }^{4}$, MEDINA; Lízia Coelho Medina ${ }^{5}$

\section{RESUMO}

Este breve estudo aborda a mediação argumentativa na aplicação de metodologias ativas em ensino de Direito a distância. Consiste em um estudo propositivo, com pesquisa bibliográfica, envolvendo análises qualitativas da questão selecionada. Justifica-se a relevância do tema pelo advento dos cursos de Direito a distância, bem como pelas possibilidades metodológicas de tal modalidade de ensino, diante das formas consagradas pelo ensino jurídico presencial. O objetivo geral do artigo é mapear o uso de metodologias ativas na educação a distância, bem como suas possibilidades e deficiências, com a proposição do uso argumentativo jurídico no âmbito do ensino de Direito, em todas as fases da relação entre ensino e aprendizagem. Nesse aspecto, a utilização de metodologias ativas, potencializadas pelo ensino a distância, atende às Diretrizes Curriculares Nacionais dos cursos jurídicos. Torna-se possível afirmar, com base nos estudos científicos já publicados, que as metodologias ativas são capazes de promover um processo de ensino e aprendizagem satisfatório em cursos a distância. Entretanto, para que isso aconteça, propõe-se o uso da argumentação jurídica na construção do conhecimento do estudante. Assim, considera-se a moderna acepção da argumentação jurídica, a qual confere a esse campo de conhecimento múltiplas dimensões de estudo e de aplicação efetiva. Pretende-se a análise da utilização da razão argumentativa - em contraponto à lógica demonstrativa, incompatível com o ensino jurídico - como fundamento epistemológico para a utilização de metodologias ativas de aprendizagem no ensino de Direito a distância. Dessa forma, propõe-se extrapolar a argumentação de seus lócus usuais, tais como a produção, a sistematização e a aplicação do Direito. Trata-se, portanto, de inserir um caráter argumentativo no âmbito do próprio ensino jurídico de graduação, mediante metodologias de ensino a distância, cujo caráter dialógico e responsivo confere, simultaneamente, aprofundamento e apropriação individualizada da relação entre ensino e aprendizagem. Nesse sentido, as particularidades temporais e espaciais possibilitadas pelo ensino a distância permitem que recursos imprescindíveis ao desenvolvimento pleno do operador do direito sejam explorados ainda nos primeiros contatos com os institutos jurídicos. A realização de salas de aula invertidas, com segmentação de conteúdos teóricos, acadêmicos e práticos em fóruns específicos de discussão, em estudos de caso e situações problema são exemplos de metodologias de ensino potencializadas pelo ensino a distância. Não obstante, os mesmos estudos 
demonstram que a evasão, a dificuldade de compreensão e o absenteísmo consistem no principal óbice para tais metodologias de ensino em outros campos do conhecimento. Por conseguinte, propõe-se o caráter imprescindível da interação argumentativa entre professor, tutor e estudante, em todas as etapas e acepções do ensino e da aprendizagem.

PALAVRAS-CHAVE: Argumentação e ensino de Direito, EaD, Metodologias ativas 